\title{
Intergenerational family caregiving in welfare policy context
}

Published as:

Dykstra P. A. (2019) Intergenerational family caregiving in welfare policy context. In D. Gu \& M. Dupre (Eds.), Encyclopedia of gerontology and population aging. Cham, CH: Springer. DOI: https://doi.org/10.1007/978-3-319-69892-2_21-1

Pearl A. Dykstra

Department of Public Administration \& Sociology, Erasmus University Rotterdam, Netherlands

dykstra@essb.eur.nl

\section{Synonyms}

Cross-national differences in adult child-parent relationships; Intergenerational family exchanges and welfare regimes; Intergenerational care regimes

\section{Definition}

Intergenerational family caregiving refers to exchanges up and down family lines aimed at nurturing the needs of others. Caregiving is more than a task; it involves emotional and relationship work.

\section{Overview}

Feminist theorists have emphasized the need to recognize caregiving — the unpaid activities aimed at serving the physical and emotional needs of dependent children and adults_-as a defining feature of women’s lives (Finch and Groves 1983; Goldscheider, Bernhardt and Lappegård 2015).). Comparative welfare state scholars have emphasized that caregiving responsibilities are divided in varying ways between the state, market, voluntary sector, and families (Evers 1993). A focus on differences in intergenerational caregiving relationships in families across welfare policy contexts connects these two theoretical stands 
in the care literature. It not only draws attention to women's and men's respective contributions to caring for older and younger family members, but also to the policy, normative and economic frameworks in which family caring responsibilities are carried out (Daly and Lewis 2000).

In the hierarchy of policy goals, labor market participation tends to come first, primarily as a means of promoting economic growth and competitiveness (Lewis and Giullari 2005). The overwhelming emphasis has been on the provision of cash benefits, leaves and care services as a means to achieve higher levels of female employment. Much less attention has been paid to the pursuit of gender equality in respect of caregiving in families. Public policy regimes differ considerably in the extent to which they have shifted from equal pay and treatment to a more equal sharing of paid and unpaid work between men and women (Folbre 2018).

\section{Key research findings}

\section{Crowding out}

Policy concerns about the implications of publicly funded services for family members’ propensity to care for their dependents fueled early research on the intersection of family care and the welfare state. By now, findings have repeatedly shown that generous welfare state services complement rather than “crowd out” family care (Motel-Klingebiel, Tesch-Römer and Von Kondratowitz 2005). The availability of social service professionals in a given country shapes the types of supportive tasks that adult children perform for their aging parents. It is crucial to distinguish practical help (e.g., assistance with household tasks, paperwork) and physical care (e.g., assistance with bathing, dressing, eating) given to parents. Using data from the Survey of Health, Ageing and Retirement in Europe (SHARE), Brandt, Haberkern and Szydlik (2009) show that the proportion of adult children providing practical help to parents is higher, but the proportion providing physical care is lower in 
countries with a larger social service sector (Brandt, Haberkern and Szydlik 2009). There is a “crowding in” of practical help, but a “crowding out” of physical care. When professionals take on the complex, demanding and routinizable physical care tasks, family members have greater opportunities to provide spontaneous and non-technical forms of help.

\section{Social risks of caregiving}

With their focus on possible declines in family solidarity, “crowding out” studies neglected the social risks of family caregiving. Time transfers have important implications for the labor supply of family helpers as well as their capital accumulation. Women are more likely than men to face a "pension penalty” (Evandrou and Glaser 2003). Their greater contributions to family care constitute “costly attachments” (Folbre 2018: p. 752), making them less attractive to employers and influencing their labor supply decisions in ways that reduce earnings. The direction of causality flows in both ways: caregivers choose to reduce their working hours or to stop working in response to needs of loved ones, whereas individuals with poor labor market opportunities are more likely to become caregivers than individuals with better labor market prospects (Carr et al. 2018; Nguyen and Connelly 2014).

Public policy arrangements not only shape the frequency and intensity of family caregiving, but also the social risks of such engagement. A key issue concerns generational interdependence (Dykstra and Hagestad 2016; Hagestad and Dykstra 2016): the extent to which public policy arrangements impose reliance on older and younger family members or enable individual autonomy (Frericks, Jensen and Pfau-Effinger 2014; Leitner 2003; Lohmann and Zagel 2016; Saraceno and Keck 2010). Note that the actual impact of public policy arrangements on family caregiving practices is not easily determined. Their effect is entwined with cultural ideals about "proper” family relations (Saraceno and Keck 2010). An additional complexity is that socioeconomic factors such as gender pay gaps and the 
availability of jobs shape men's and women's behavior in families (Gornick and Hegewisch 2015).

To understand the family/state division of responsibility for the old and the young, Saraceno and Keck (2010) distinguish three patterns in policy frameworks. The first is familialism by default, implying that there are few or no publicly provided alternatives to family care (high levels of generational interdependence). The second is supported familialism, where there are policies, usually in the form of cash for care benefits and paid leaves, which support families in keeping up their caring responsibilities (intermediate levels of generational interdependence). The third is defamilialization, where needs are partly addressed through the provision of services (day care, home help, residential care), resulting in low levels of generational interdependence. The authors' analysis of policies shows that in individual countries of the European Union the same pattern does not always emerge regarding responsibilities for the young and those for the old. In the Netherlands, for example, there is little publicly funded support for parents caring for infant children (familialism by default), but there are extensive welfare services for impaired older adults (defamilialization). Furthermore, contrary to widespread opinion, supported familialism and defamilialization are not always contrasting policy approaches. In some countries, as also pointed out by Eggers, Grages, Pfau-Effinger and Och (2018), they actually represent part of an integrated approach to public support of intergenerational responsibilities. In Denmark, for example, there is generous public funding both for professional care and for care performed by family members. Citizens have an actual choice (Leitner 2003) between caring themselves (and maintaining financial autonomy) or being (partly) relieved from caregiving responsibilities because qualified employees step in to help.

Research on grandparental care provides a powerful example of how policy arrangements structure generational interdependence across three family generations. 
Combining data from SHARE with data from the Multilinks Database on Intergenerational Policy Indicators (Keck and Saraceno 2012), Bordone, Arpino and Aassve (2017) examine the likelihood that grandparents care for the children of an employed daughter or daughter-inlaw on a daily basis. Findings show that grandparents are most likely to be daily caregivers in countries where public childcare services and parental leaves are least generous (Italy, Greece, Spain, and Poland). They are least likely to care for grandchildren on a daily basis in countries that score the best in terms of childcare services (e.g. Belgium), parental leave (e.g. the Czech Republic), or both types of arrangements (e.g. Denmark). In the latter set of countries, grandparents are not compelled to step in—because there are public arrangements facilitating the combination of paid work and parenting responsibilities. Tobío (2007) argues that grandparental care in Southern European countries is part of an effort to improve the life chances of the middle generation. Paradoxically, she notes, Spanish grandmothers assume an old-fashioned role (withdrawing from the labor force) to enable their daughters to be gainfully employed.

\section{Gendered implications of family caregiving policies}

Increasingly, research is being carried out on the gendered implications of family caregiving policies. Eggers, Grages, Pfau-Effinger and Och (2018) provide a ranking in terms of their support for gender equality of the long-term care (LTC) policies (services and cash for care) of five European countries with different welfare state traditions. Liberating relatives from care obligations by providing comprehensive professional care, and/or ensuring the financial autonomy of family carers yield high scores. In Denmark, generosity is high for both types of LTC policy, in Germany and the Czech Republic both types of LTC policy show about medium generosity, while the generosity is around a low level in Italy and Ireland. Using data from the European Quality of Life Survey, the authors show that the gender gap among people aged 55-64 who provide daily care to older relatives is lowest in 
Denmark and highest in Ireland and Italy. Similar country differences emerge for the gender gap in employment rates of people aged 55-64 based on OECD Labour Force Statistics.

A drawback of the Eggers et al. study is that different types of LTC policies are considered as a package, thereby overlooking the gendered impact of specific policy measures. When public care support is offered in cash rather than in kind, the strategy of keeping the money for the family budget and staying at home to provide care is more attractive for women than men, given that men tend to have higher earnings (Frericks, Jensen and Pfau-Effinger 2014; Javornik 2014; Lohmann and Zagel 2016; Rummery 2009; Saraceno 2010). As noted earlier, reduced participation in gainful employment contributes to a greater likelihood of old-age poverty among women. Using SHARE data, and confirming earlier findings, Haberkern, Schmid, and Szydlik (2015) show that women are more likely to provide intensive care to aging parents than men are. However, the gender gap in the provision of such care is highest in countries with low provision of professional home-care services and high public spending on cash benefits. Additional analyses reveal that professional home-care services substitute only for care by daughters, not for care by sons, who show lower levels of engagement generally. Moreover, cash payments encourage intergenerational care, but motivate only daughters not sons. Apparently, public services (home help and home nursing) reduce inequality in intergenerational care by reducing the engagement of daughters, whereas cash for care payments increase inequality in intergenerational care by increasing the engagement of daughters. In general, care-giving by sons is hardly influenced by social care policies.

\section{Future directions of research}

Cross-national comparisons constitute a valuable strategy to uncover how public policy arrangements in Europe create and reinforce generational interdependencies in the family realm or- on the contrary—-lighten them. The literature provides telling descriptions 
of the links between public and family streams of support. Significant progress has been made in compiling harmonized indicators of public policy arrangements, enabling country comparisons - which dominate in research. Remarkably few studies have examined the impact of changes in public policy arrangements for caregiving in families. Contemporary neo-liberal welfare state restructuring would appear to provide a fruitful basis for gaining insight into how macro-level processes shape intergenerational family practices. Future research will benefit from within-country analyses of changes in welfare policy context for gender and socioeconomic inequalities in multigenerational families. Natural experiments, where changes in types and levels of public provisions might be linked to changes in intergenerational family practices, should be considered more often.

Considerable progress has been made in describing how the welfare policy context shapes generational interdependence in families. Yet, there are opportunities to improve and expand this scientific body of knowledge. One avenue is to more judiciously theorize about connections between public policy arrangements (or their absence) and expectations, obligations, rights, and vulnerabilities at the individual level of people’s lives. Another avenue involves more critical empirical assessments of theoretical mechanisms. What are the incentives, the motives, the power relations? Moreover, instead of solely relying on macrolevel policy indicators, knowledge about family members' eligibility to benefits and their actual use of benefits will help clarify patterns of intergenerational assistance. With increasing access to national registry data, European countries offer a unique laboratory for the assessment of policy impacts.

\section{Summary}

Generous welfare state services complement rather than “crowd out” intergenerational family caregiving. When publicly funded professionals take on the demanding physical care tasks, family members have greater opportunities to provide spontaneous and non-technical 
forms of help. Public policy arrangements not only shape the frequency and intensity of family caregiving, but also the social risks of such engagement. Contributions to family care are linked with a reduced labor supply of family helpers and reduced capital accumulation. A key issue concerns generational interdependence: the extent to which public policy arrangements impose reliance on older and younger family members or enable individual autonomy. Generational interdependence is high when there are few publicly provided alternatives to family care, intermediate when policies such as cash for care benefits and paid leaves support families in keeping up their caring responsibilities, and low when care needs are partly addressed through the provision of services such as day care, home help, and residential care. New insights have emerged on the gendered implications of family caregiving policies. When public care support is offered in cash rather than in kind, the strategy of staying at home to provide care is more attractive for women than men, given that men tend to have higher earnings. The gender gap in the provision of intensive care to aging parents (women more often providing such care than men) is highest in countries with low provision of professional home-care services and high public spending on cash benefits.

\section{Cross-references}

Intergenerational housing; Caregiver credits; Fee-for-service; primary caregiver; formal/informal care; coresidence; sandwich generation; gender and caring in later life; midlife and gender; caregiving and social support—similarities and differences; employment and caregiving; self, informal and form care-the interface; Intergenerational exchange and support; Intergenerational family structures; Intergenerational solidarity; Parent-child relationships; Subjective well-being and life satisfaction by eldercare providers and recipients; Intergenerational exchanges; Social support; Familism; Home and communitybased services (HCBS)

\section{References}


Bordone V, Arpino B, Aassve A (2017) Patterns of grandparental child care across Europe: The role of the policy context and working mothers' need. Ageing Soc, 37: 845-873. http://dx.doi.org/10.1017/S0144686X1600009X

Brandt M, Haberkern K, Szydlik M (2009) Intergenerational help and care in Europe. Eur Sociol Rev, 25: 585-601. doi: 10.1093/esr/jcn076

Carr E, Murray ET, Zaninotto P, et al. (2018) The association between informal caregiving and exit from employment among older workers: Prospective findings from the UK Household Longitudinal Study. J Geront: Soc Sci, 73:1253-1262. doi:10.1093/geronb/gbw156

Daly M, Lewis, J (2000) The concept of social care and the analysis of contemporary welfare states. Br J Sociol, 51: 281-298. https://doi.org/10.1111/j.1468-4446.2000.00281.x

Dykstra PA, Hagestad, GO (2016) How demographic patterns and social policies shape interdependence among lives in the family realm. Popul Horiz, 13: 54-62. doi: https://doi.org/10.1515/pophzn-2016-0004

Eggers T, Grages C, Pfau-Effinger B, Och R (2018) Re-conceptualising the relationship between de-familialisation and familialisation and the implications for gender equality - the case of long-term care policies for older people. Ageing Soc. doi:10.1017/S0144686X18001435

Evandrou M, Glaser K. (2003) Combining work and family life: The pension penalty of caring. Ageing Soc, 23: 583-601. doi: 10.1017/S0144686X03001314

Evers A. (1993) The welfare mix approach: Understanding the pluralism of welfare systems. In: Evers A, Svetlik I (eds) Balancing pluralism: New welfare mixes in care for the elderly. Avebury, Aldershot UK, pp 3-31

Finch J, Groves D. (1983) Labour and love: Women, work and caring. Routledge \& Kegan Paul, London 
Folbre N. (2018) The care penalty and gender inequality. In: Averett SL, Argys LM, Hoffman, SD (eds) The Oxford handbook of women and the economy. Oxford University Press, New York, pp 749-766. doi:

10.1093/oxfordhb/9780190628963.013.2

Frericks P, Jensen PH, Pfau-Effinger B. (2014) Social rights and employment rights related to family care: Family care regimes in Europe. J Aging Stud, 29: 66-77. https://doi.org/10.1016/j.jaging.2013.12.002

Goldscheider F, Bernhardt E, Lappegård, T. (2015) The gender revolution: A framework for understanding changing family and demographic behavior. Pop Dev Review, 41: 207239. https://doi.org/10.1111/j.1728-4457.2015.00045.x

Gornick JC, Hegewisch A (2015) Gender, employment, and parenthood: The consequences of work-family policies. In: Keleman D (ed) Lessons from Europe? What Americans can learn from European public policies. Sage, Los Angeles, pp 17-41

Haberkern K, Schmid T, Szydlik M (2015) Gender differences in intergenerational care in European welfare states. Ageing Soc, 35:298-320

Hagestad GO, Dykstra PA. (2016) Structuration of the life course: Some neglected aspects. In: Shanahan MJ, Mortimer JT, Kirkpatrick Johnson M (eds) Handbook of the life course, Volume II. Springer, New York, pp 131-157. DOI 10.1007/978-3-319-208800_6

Javornik J (2014) Measuring state de-familialism: Contesting post-socialist exceptionalism. J Eur Social Policy, 24: 240-257. doi: 10.1177/0958928714525815

Keck W, Saraceno C (2012) Multilinks database on intergenerational policy indicators. Journal of Contextual Economics—Schmollers Jahrbuch, 132: 453-461. doi: https://doi.org/10.3790/schm.132.3.453 
Leitner S (2003) Varieties of familialism: The caring function of the family in comparative perspective. Eur Soc, 5: 353-375. doi: 10.1080/1461669032000127642

Lewis J, Giullari S (2005) The adult worker model family, gender equality and care: the search for new policy principles and the possibilities and problems of a capabilities approach. Econ Soc, 34(1): 76-104. doi: 10.1080/0308514042000329342

Lohmann H, Zagel H (2016) Family policy in comparative perspective: The concepts and measurement of familization and defamilization. J Eur Soc Policy, 26: 48-65. doi: $10.1177 / 0958928715621712$

Motel-Klingebiel A, Tesch-Römer C, Von Kondratowitz, H-J (2005) Welfare states do not crowd out the family: Evidence for mixed responsibility from comparative analyses, Ageing Soc, 25: 863-82. doi:10.1017/S0144686X0500397

Nguyen HT, Connelly LB (2014) The effect of unpaid caregiving intensity on labour force participation: Results from a multinomial endogenous treatment model. Soc Sci Med, 100: 115-122. https://doi.org/10.1016/j.socscimed.2013.10.031

Rummery K (2009) A comparative discussion of the gendered implications of cash-for-care schemes: Markets, independence and social citizenship in crisis? Soc Pol Admin, 43: 634-648. doi: 10.1111/j.1467-9515.2009.00685.x

Saraceno C. (2010) Social inequalities in facing old-age dependency: A bi-generational perspective. J Eur Soc Policy, 20: 32-44. doi: 10.1177/0958928709352540

Saraceno C, Keck W. (2010) Can we identify intergenerational policy regimes in Europe? Eur Soc, 12: 675-696. doi: 10.1080/14616696.2010.483006

Tobío C (2007) Change and reciprocity in intergenerational relationships: The discourse of Spanish working mothers. In: Véron J, Pennec S, Légaré J (eds) Ages, generations 
and the social contract: The demographic challenges facing the welfare state.

Springer, Dordrecht, NL, pp 191-207 